\title{
First record of Thaumastocoris peregrinus (Hemiptera, Thaumastocoridae) in Pará state, Brazil
}

\author{
Ivy Laura SALIBA ${ }^{1}$, Alexandre Mehl LUNZ², Telma Fátima BATISTA ${ }^{1}$, Gustavo SCHWARTZ ${ }^{2 *}$ (1) \\ ${ }^{1}$ Universidade Federal Rural da Amazônia (UFRA), Belém, PA, Brasil \\ ${ }^{2}$ Empresa Brasileira de Pesquisa Agropecuária (Embrapa), Embrapa Amazônia Oriental, Belém, PA, Brasil \\ * Corresponding author: Gustavo.Schwartz@embrapa.br; (1D https://orcid.org/0000-0002-1717-4491
}

\begin{abstract}
Thaumastocoris peregrinus (Hemiptera, Thaumastocoridae) is a phytophagous pest of eucalyptus plantations. It was introduced in Brazil in 2008, and expanded rapidly due to its adaptive capacity to different climatic conditions. Eucalyptus has been planted in the Brazilian Amazon since the 1980s, being used in silvopastoral systems and for cellulose production. Since its introduction in the southernmost Brazilian state of Rio Grande do Sul, T. peregrinus has expanded its geographical distribution to 117 municipalities in states in the south (Rio Grande do Sul, Santa Catarina and Paraná), southeast (São Paulo, Espirito Santo, Rio de Janeiro and Minas Gerais), mid-west (Mato Grosso do Sul and Goiás) and northeast (Sergipe) of the country. Here we report the first record of T. peregrinus in the Brazilian Amazonian state of Pará.
\end{abstract}

KEYWORDS: insect pest, bronze bug, occurrence, Eucalyptus, Brazilian Amazon

\section{Primeiro registro de Thaumastocoris peregrinus (Hemiptera, Thaumastocoridae) no estado do Pará, Brasil}

\section{RESUMO}

Thaumastocoris peregrinus (Hemiptera, Thaumastocoridae) é uma praga fitófaga de plantios de eucalipto introduzida no Brasil em 2008. A espécie expandiu-se rapidamente devido à sua capacidade adaptativa a diferentes condiçóes climáticas. $\mathrm{O}$ eucalipto vem se expandindo na Amazônia brasileira desde a década de 1980, sendo usado em sistemas silvipastoris e produção de celulose. Desde a sua introdução inicial no Rio Grande do Sul, T. peregrinus expandiu sua distribuição geográfica a 117 municípios nos estados sul (Rio Grande do Sul, Santa Catarina e Paraná), sudeste (São Paulo, Espirito Santo, Rio de Janeiro e Minas Gerais), centro-oeste (Mato Grosso do Sul e Goiás) e nordeste (Sergipe) do país. Aqui relatamos o primeiro registro de T. peregrinus no estado do Pará, Brasil.

PALAVRAS-CHAVE: praga agrícola, percevejo-bronzeado, ocorrência, Eucalyptus, Amazônia

Thaumastocoris peregrinus Carpintero \& Dellapé (Hemiptera, Thaumastocoridae) is a phytophagous pest in both immature and adult stages that occurs in eucalyptus plantations (Carpintero and Dellapé 2006). Attacked trees present symptoms such as drying and color change of the leaves, that change from their natural silvery color to brown-reddish. It is from this leaf color of infested trees, that the insect derives its common name, bronze bug (Jacobs and Nesser 2005; Wilcken et al. 2010). Intense $T$. peregrinus infestations cause partial or total defoliation that results in the reduction of the trees photosynthetic area (Penteado et al. 2014) and the consequent decrease in its productivity (Lunz and Azevedo 2016), eventually leading to the death of the tree.

Thaumastocoris peregrinus feeds on eucalyptus by making small incisions on the leaves (Lorencetti et al. 2015; Cipriani et al. 2015). The adult insect is $3-4 \mathrm{~mm}$ long with a brown flattened body that varies according to the development phase (Jacobs and Nesser 2005; Lorencetti et al. 2015; Lunz and Azevedo 2016). Females of T. peregrinus lay an average of 60 black eggs on eucalyptus leaves. The development involves five nymph instars (Jacobs and Nesser 2005) and an approximate 60 -day life cycle that can vary with climate conditions (Penteado et al. 2014). Generations overlap along the year, so that great numbers of nymphs and adults can occur simultaneously (Noack and Rose 2007).

Originated from Australia, T. peregrinus was first recorded in South America in November 2005, in the north of Buenos Aires, Argentina (Noack and Coviella 2006), and later in Uruguay, in January 2008 (Martínez and Bianchi 2010). In Brazil, the species was first recorded in early 2008, in the municipality of São Francisco de Assis, in the southern state 
of Rio Grande do Sul (Table 1), in hybrid clones of Eucalyptus urograndis and E. urophylla (Wilcken et al. 2010).

The insect rapidly dispersed over eucalyptus plantations throughout Brazil (Figure 1) due to its adaptive capacity, since it can survive under different climate conditions (Pereira $e t$ al. 2013). Other favorable aspects for the rapid dispersion of T. peregrinus were the transport of infested vegetal material of eucalyptus across producing regions (Wilcken et al. 2010) and fragile phytosanitary barriers among producing states (Lunz and Azevedo 2016).

In the southeastern region of the state of Pará, in the eastern Brazilian Amazon, soil and climatic conditions are favorable to the development of eucalyptus plantations (Filgueiras et al. 2011). Today, Pará is the $10^{\text {th }}$ Brazilian state in area planted with eucalyptus, with almost 134,000 ha, being mainly used to supply the energy and cellulose markets (IBA 2017). Reports on the occurrence of new dangerous biotic agents in these plantations are scarce, which is likely due to the lack of periodic monitoring by plantation owners.
Here we provide information on the occurrence of $T$. peregrinus in eucalyptus plantations from Pará state, extending the geographic distribution of this pest in Brazil. Sampling was carried out in 2015 and 2016, in areas of commercial plantations of Eucalyptus spp. in southeastern Pará, in the municipalities of Paragominas $\left(03^{\circ} 20^{\prime} 07.08^{\prime} \mathrm{S}, 47^{\circ} 11^{\prime} 21.54\right.$ ” W), Ulianópolis (0358'26.50”S, 47³3’01.96”W), Dom Eliseu

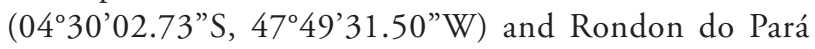

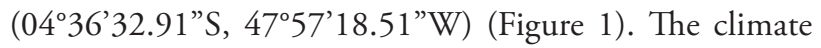
type is Awi, according to the Köppen classification. Yellow sticky traps (ISCA Technologies, Brazil) were used in 32 georeferenced points. Traps were placed in the interior of the plantations, at least $100 \mathrm{~m}$ from the border. Each trap was located between two trees at $1.60 \mathrm{~m}$ from the soil. Traps were replaced monthly. Retrieved traps were analyzed at an entomology laboratory at Universidade Federal Rural da Amazônia, in Belém (Pará state, Brazil) under a stereoscopic microscope QM Q7714Z. Specimens of T. peregrinus were identified through the use of taxonomic keys by

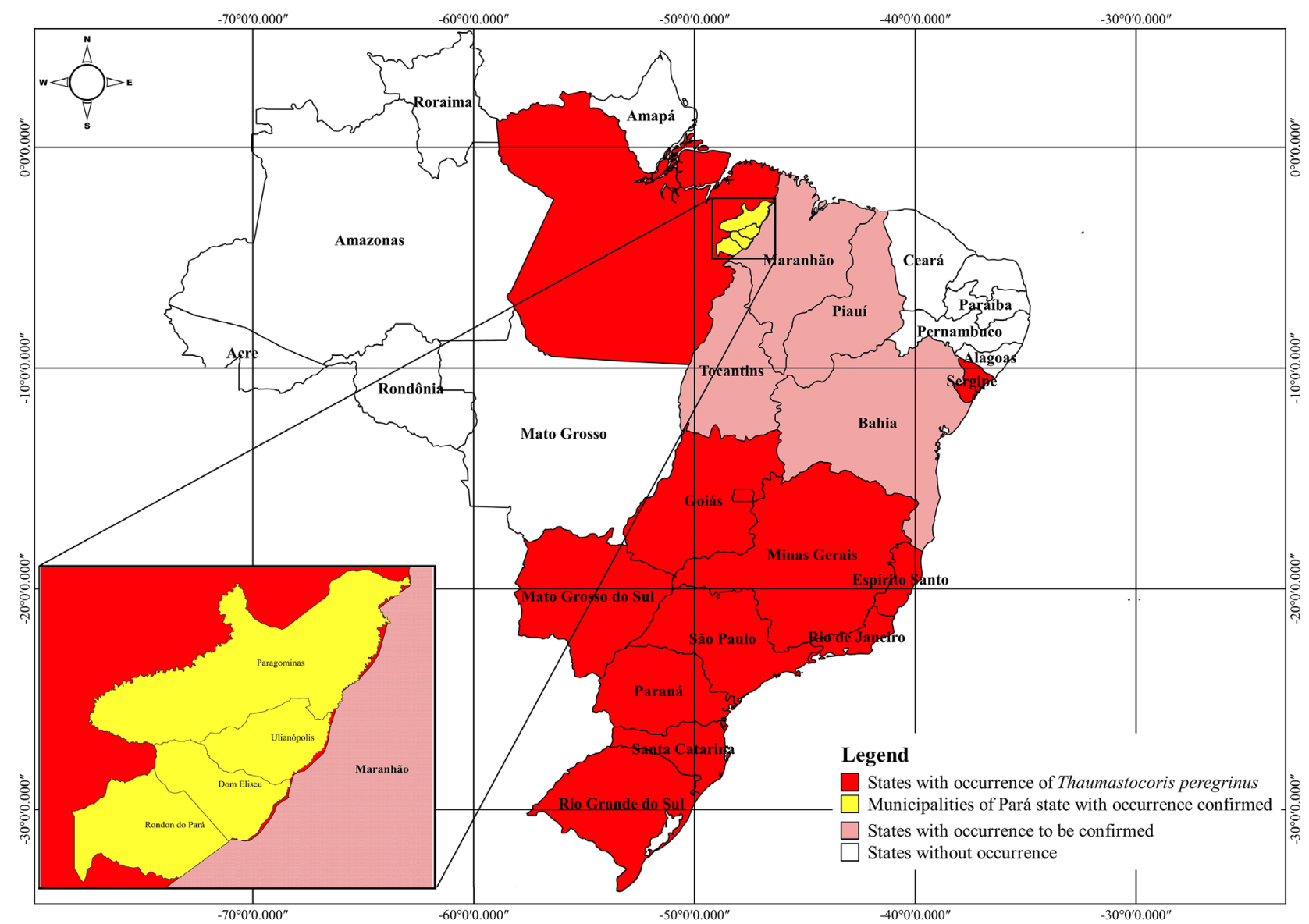

Figure 1. Distribution of the bronze bug, Thaumastocoris peregrinus in Brazil, showing in red the states with confirmed occurrences. The first record was in the southern state of Rio Grande do Sul in 2008 (see Table 1 for first records in other states). The municipalities in Pará state where the species was first recorded (this study) are indicated in yellow. States in which the species has been reported, but no voucher-based records exist to date, are indicated in pink. This figure is in color in the electronic version 
Table 1. Chronological evolution of first records of the bronze bug, Thaumastocoris peregrinus in different Brazilian states. The first record in Brazil was in Rio Grande do Sul state in January 2008.

\begin{tabular}{lccc}
\hline $\begin{array}{l}\text { Date of first } \\
\text { record }\end{array}$ & $\begin{array}{c}\text { Number of } \\
\text { municipalities }\end{array}$ & State & Source \\
\hline Early 2008 & 1 & Rio Grande do Sul & Wilcken et al. (2010) \\
\hline January 2009 & 9 & Rio Grande do Sul & Wilcken et al. (2010) \\
\hline April 2009 & 13 & Rio Grande do Sul & Savaris et al. (2011 \\
\hline April 2009 & 4 & Santa Catarina & Savaris et al. (2011) \\
\hline October 2009 & Not defined & Paraná & Barbosa et al. (2010) \\
\hline 2012 & 1 & Paraná & Lorencetti et al. (2015) \\
\hline June 2008 & 1 & São Paulo & Wilcken (2008) \\
\hline October 2009 & 74 & São Paulo & Wilcken et al. (2010) \\
\hline July 2009 & 1 & Espírito Santo & Wilcken et al. (2010) \\
\hline October 2009 & 1 & Rio de Janeiro & Wilcken et al. (2010) \\
\hline December 2008 & 2 & Minas Gerais & Wilcken et al. (2010) \\
\hline October 2009 & 2 & Mato Grosso do Sul & Wilcken et al. (2010) \\
\hline November 2011 & 3 & Goiás & Pereira et al. (2013) \\
\hline 2015 & 1 & Sergipe & Ribeiro et al. (2015) \\
\hline 2015 & 4 & Pará & This study \\
\hline
\end{tabular}

Carpintero and Dellapé (2006) and Wilcken et al. (2010). Voucher specimens of the collections were deposited in the entomological collection of Embrapa Amazônia Oriental in Belém, Pará, Brazil, under number 2444. Quantitative data of these samplings will be analyzed elsewhere.

A total of 1,358 individuals were collected, 438 (32.2\%) in 2015 and $920(67.8 \%)$ in 2016, in all four municipalities sampled. Thaumastocoris peregrinus occurred in clones of $E$. camaldulensis, E. urophylla, E. grandis, and in hybrid clones of E. camaldulensis. Nymphs and eggs were also observed in neighbor trees around the traps, but these trees showed no sign of serious damage.

Many eucalyptus species are attacked by $T$. peregrinus, especially E. camaldulensis and the hybrid E. urograndis (Queiroz 2009). Moreover, E. camaldulensis is considered as the most susceptible eucalyptus species to insect pests (Wilcken 2008). Thaumastocoris peregrinus also attacks $E$. tereticornis and the hybrid of E. camaldulensis $\mathrm{x}$ E. grandis (Jacobs and Nesser 2005). Eucalyptus urophylla and E. grandis were also very susceptible to T. peregrinus attacks (Soliman et al. 2012).

Increases in plantation areas normally result in increases in insect species that adapt themselves to the crops (Costa and Araldi 2014). Exotic insect pests in forest plantations can be a threat to forest productivity due to the economic losses coming from plantation damages caused by these insects (Garlet et al. 2016). There is scarce information regarding the efficient management of $T$. peregrinus.

Probably the T. peregrinus invasion in Pará started from eucalyptus plantations in the neighboring state of Maranháo, where the presence of $T$. peregrinus has been reported in newsfeeds (SAGRIMA 2014), although no voucher-based record exists yet of the occurrence of the species in this state. Eucalyptus has been cultivated in Pará for more than 30 years without adequate insect pest monitoring by plantation owners. Based on the pest's first records in the mid-western state of Goiás (Table 1 ) it is reasonable to estimate that $T$. peregrinus is in Pará since 2013. Furthermore, T. peregrinus can also be present in eucalyptus plantations in Bahia, Piauí, Maranhão and Tocantins (Figure 1), although there are no scientific records of its occurrence published for these states.

Our findings highlight the importance of using periodic and systematic monitoring methods to determine pest infestation levels and population dynamics in eucalyptus commercial plantations, and which eucalyptus species are more susceptible to pests. Systematic studies also help to identify possible native natural enemies of pest species that could favor the use of ecological pest management.

Since its first occurrence, and including the records we present in here, T. peregrinus has now been recorded in 117 Brazilian municipalities, and in 11 federal states (Table 1)

\section{ACKNOWLEDGMENTS}

We are grateful to Conselho Nacional de Desenvolvimento Científico e Tecnológico - CNPq (project \# 474457/2013$3 \mathrm{CNPq} /$ Universal call for proposals nr. 14, Faixa B), and to Empresa Brasileira de Pesquisa Agropecuária - Embrapa (project \# 02.12.01.028.00.00 Embrapa/Macroprograma 2) for funding, which made this work possible.

\section{REFERENCES}

Barbosa, L.R.; Santos, F.; Wilcken, C.F.; Soliman, E.P. 2010. Registro de Thaumastocoris peregrinus (Hemiltera, Thaumastocoridae) no Estado do Paraná. Pesquisa Florestal Brasileira, 30: 75-77.

Carpintero, D.L.; Dellapé, P.M. 2006. A new species of Thaumastocoris Kirkaldy from Argentina (Heteroptera: Thaumastocoridae: Thaumastocorinae). Zootaxa, 1228: 61-68.

Cipriani, H.N.; Vieira, A.H.; Rocha, R.B.; Costa, J.N.M.; Mendes, A.M.; Araújo, L.V.; Vieira Junior, J.R. 2015. Cultivo do eucalipto para madeira em Rondônia. Sistemas de Produção n. 35, Embrapa Rondônia, Porto Velho, 85p.

Costa, C.E.; Araldi, D.B. 2014. Entomofauna florestal: uma visão holística. In: Cantarelli, E.B.; Costa, E.C. (Org.). Entomologia Florestal Aplicada. 1st ed., UFSM, Santa Maria, p.13-34.

Filgueiras, G.C.; Mota Junior, K.J.A.; Silva, R.P.; Bentes, E.S. 2011. Análise e perspectivas para o desenvolvimento da Silvicultura no Estado do Pará. Amazônia: Ciência e Desenvolvimento, 7: 33-59.

Garlet, J.; Costa, E.C.; Boscardin, J. 2016. Levantamento da entomofauna em plantios de Eucalyptus spp. por meio de armadilha luminosa em São Francisco de Assis - RS. Ciência Florestal, 26: 365-374.

IBA. 2017. Indústria Brasileira de Árvores. Annual report, Brasília, 80p. (https://iba.org/images/shared/Biblioteca/IBA_ RelatorioAnual2017.pdf). Accessed on 10 Apr 2018. 
Jacobs, D.H.; Neser, S. 2005. Thaumastocoris australicus Kirkaldy (Heteroptera: Thaumastocoridae): a new insect arrival in South Africa, damaging to Eucalyptus trees: research in action. South African Journal of Science, 101: 233-236.

Lorencetti, G.A.T.; Potrich, M.; Silva, E.L.R.; Mazaro, S.M.; Barbosa, L.R. 2015. Registro de Thaumastocoris peregrinus Carpintero e Dellapé na Região Sudoeste do Paraná. Floresta e Ambiente, 22: 434-436.

Lunz, A.M.; Azevedo, R. 2016. Eucalipto. In: Silva, N.M.; Adaime, R.; Zucchi, R.A. (Eds.). Pragas agrícolas e florestais na Amazônia. Embrapa, Brasília, p.461-471.

Martínez, G.; Bianchi, M. 2010. Primer registro para Uruguay de la chinche del eucalipto, Thaumastocoris peregrinus Carpintero y Dellappé, 2006 (Hemipera; Thaumastocoridae). Agrociencia, 14: 15-18.

Noack, A.E.; Coviella, C.E. 2006. Thaumastocoris australicus Kirkaldy (Hemiptera: Thaumastocoridae): first Record of this invasive pest of Eucalyptus in the Americas. General and Applied Entomology, 35: 13-14.

Noack, A.E; Rose, H. 2007. Life-history of Thaumastocoris peregrinus and Thaumastocoris sp. in the laboratory with some observations on behaviour. General and Applied Entomology, 36: 27-33.

Penteado, S.R.C.; Queiróz, D.L.; Barbosa, L.R. 2014. Insetos sugadores em plantações de Pinus e Eucalyptus no Brasil. In: Cantarelli, E.B.; Costa, E.C. (Org.). Entomologia Florestal Aplicada. 3rd ed., UFSM, Santa Maria, p.71-99.

Pereira, J.M.; Melo, A.P.C.; Fernandes, P.M.; Soliman, E.P. 2013. Ocorrência de Thaumastocoris peregrinus Carpintero \& Dellapé (Hemiptera: Thaumastocoridae) no Estado de Goiás. Ciência Rural, 43: 254-257.

Queiroz, D.L. 2009. Pragas Exóticas e Potenciais à Eucaliptocultura no Brasil. In: Zacaroni, A.B.; Toyota, M.; Ferro, H.M.; Teixeira, G.A.; Almeida, J.E.M.; Fernandes, L.H.M.; Freire, E.S.; Pereira, V.F.; Carvalho, E.A.; Lelis, F.M.V. (Orgs.). Manejo Fitossanitário de Cultivos Agroenergéticos. Sociedade Brasileira de Fitopatologia, Brasília, p.239-249.
Ribeiro, G.T.; Sá, J.S.; Rolim, G.S.; Correia-Oliveira, M.E.; Mendonça, M.C.; Poderoso, J.C.M. 2015. First report Thaumastocoris peregrinus in Eucalyptus plantations in the state of Sergipe, Brazil (Hemiptera: Thaumastocoridae). Entomologica Americana, 121: 23-26.

SAGRIMA. 2014. Secretaria de Estado da Agricultura Pecuária e Pesca, Agência Estadual de Defesa Agropecuária. AGED avalia incidência de pragas de impacto econômico nas florestas de eucalipto. (http://www.sagrima.ma.gov.br/aged-avaliaincidencia-de-pragas-de-impacto-economico-nas-florestas-deeucalipto/). Accessed on 01 Apr 2019.

Savaris, M.; Lampert, S.; Pereira, P.R.V.S.; Salvadori; J.R. 2011. Primeiro registro de Thaumastocoris peregrinus para o estado de Santa Catarina, e novas áreas de ocorrência para o Rio Grande do Sul, Brasil. Ciência Rural, 41: 1874-1876.

Soliman, E.P.; Wilcken, C.F.; Pereira, J.M.; Dias, T.K.R.; Zaché, B.; Dal Pogetto, M.H.F.A. 2012. Biology of Thaumastocoris peregrinus in different eucalyptus species and hybrids. Phytoparasitica, 40: 223-230.

Wilcken, C.F. 2008 Percevejo bronzeado do eucalipto Thaumastocoris peregrinus (Hemiptera: Thaumastocoridae): ameaça às florestas de eucalipto brasileiras. Programa de Proteção Florestal - PROTEF, Instituto de Pesquisas e Estudos Florestais - IPEF, Botucatu. 11p. (https://www.ipef.br/protecao/alerta-percevejo.pdf). Accessed on 24 May 2019.

Wilcken, C.F.; Soliman, E.P.; Nogueira De Sá, L.A.; Barbosa, L.; Dias, T.K.R.; Ferreira Filho, P.J.; Oliveira, R.J.R. 2010. Bronze bug Thaumastocoris peregrinus Carpintero \& Dellapé (Hemiptera: Thaumastocoridae) on Eucalyptus in Brazil and its distribution. Journal of Plant Protection Research, 50: 201-205.

RECEIVED: $13 / 08 / 2018$

ACCEPTED: $12 / 05 / 2019$

ASSOCIATE EDITOR: Pitágoras C. Bispo 